\title{
ATTRIBUTES THAT CONTRIBUTE TO GUEST SATISFACTION: A COMPARATIVE STUDY OF REVIEWS POSTED ON BOOKING.COM AND ON AIRBNB'S PLATFORM
}

\author{
DOI: https://doi.org/10.18509/AGB.2020.01
}

UDC: 004.775:004.457'23:[338.48:640.412

\author{
István Egresi, Viorel Puiu, Vasile Zotic, Diana Alexandru
}

Center for Research on Settlements and Urbanism, Faculty of Geography, Babes-Bolyai University, Cluj-Napoca, Romania

corresponding author: viorel.puiu@ubbcluj.ro

\author{
submitted: 25.02 .2019 \\ accepted: 20.05 .2019 \\ published: 01.09.2019
}

\begin{abstract}
User-generated content (UGC) is a powerful tool used to attract tourists to a destination and to market certain tourism products and services. Reviews of hotels and other tourism accommodation rentals are increasingly used by travelers to select their accommodation, thus, facilitating independent travel planning. This study is attempting to understand and compare the factors that contribute to customer satisfaction for hotel and Airbnb apartment guests in Cluj-Napoca, Romania. We employed reviews published by users on booking.com (for hotel customers) and on the Airbnb platform between May and November 2018 and quantitatively and qualitatively analyzed them using QDA Miner and Wordstat to understand the main attributes associated with guest satisfaction. The study revealed that the two lists of attributes that determine guest satisfaction are, to a great extent, similar. This means that guests have the same criteria in mind when evaluating their hotel and Airbnb stay. However, two attributes were found to be important only to Airbnb guests ("good communication" and "easy check-in/out") and three to hotel guests ("good breakfast", "nice view" and "parking"). The findings have a number of theoretical and managerial implications which are discussed at the end of the paper.
\end{abstract}

Keywords: attributes of guest satisfaction, Airbnb, user-generated content (UGC), electronic-word-of-mouth (eWOM), text analytics

\section{INTRODUCTION}

Over the last few years, we have witnessed the explosive growth of an alternative economic model, known as the "sharing economy" or "collaborative consumption" [7]. This economic model is based on the use of internet platforms that allow individuals to lend, borrow, gift, swap or rent consumer products and services [34].

Airbnb is one of the most successful examples of companies involved in the "sharing economy" [44], [48]. Founded in 2008 in San Francisco, USA, by 2018, the platform was already operational in 191 countries and featured just under five million listings [2]. By the same year, the platform already registered over 300 million bookings [2]. However, given the tremendous growth rate and potential, some analysts predicted that by 2025 , Airbnb could reach a billion "room nights" per year booked through its platform [53].

Initially, due its different economic model and small size, Airbnb was not perceived as a competitor by the major hospitality corporations. However, it has become more and more clear that Airbnb does not follow the "sharing economy" model entirely [19]. Many accommodation units on Airbnb are entire apartments or houses in which the owner does not live and which were purchased not to be shared with others but to make money [11]. Some owners even have multiple listings on Airbnb. These commercially-oriented accommodation units make up $65 \%$ of Airbnb's revenue in its top 12 markets [32]. In lesser developed Airbnb markets the domination of forprofit listings is even more visible. In Warsaw, for example, Gyódi [11] found that only $11 \%$ of the Airbnb listings were part of the sharing economy. Thus, it has become quite obvious that Airbnb has started to compete with traditional hospitality businesses [17]. Moreover, the number of listings on Airbnb has increased very fast and today is comparable to the capacity of hotels [1], [2]. 
However, there are cities where Airbnb has a greater accommodation capacity than hotels, especially in Southern Europe [1].

As this rapid growth of the Airbnb network could threaten the profitability of the traditional accommodation providers, hoteliers need to quickly figure out a way to counter the expansion of home rental platforms at their expense. In order to do that, they need to know what makes hotel guests satisfied and why some customers have migrated to Airbnb or other home rental platforms. However, managers do not always understand what guests perceive as important in the selection and evaluation of accommodation [28], so that it is better to ask the customers.

Customer satisfaction is a very important issue because it could lead to repeat patronage and positive word-of-mouth [47]; thus, this study could

\section{LITERATURE REVIEW}

\section{Relationship between Airbnb and hotels}

An important question found in the literature is how has the rise of home-sharing platforms, such as Airbnb, impacted hotels. Scholars are split on this issue. Some studies argue that Airbnb accommodations do not have a negative impact on hotels or have only a minor effect. For example, Haywood et al. [21], in a study in Manhattan (USA), found no evidence that Airbnb listings have a major negative impact on hotel revenue. Moreover, a study conducted in Norway found that, in those regions in which Airbnb is doing well, hotels are also doing well while in those regions which have few Airbnb listings hotels are also suffering. Thus, the authors concluded that Airbnb must have a positive effect on the hotel market in Norway [46]. One explanation could be that hotels and Airbnb accommodations are not in direct competition - and may even be complementary - so that the growth of the Airbnb network did not disrupt the business of the hotels [22], [52].

Other studies, however, claim that the expansion of Airbnb listings has negatively affected hotels' revenues. For example, Mahmood [29] has calculated that hotels in New York City lose approximately US $\$ 450$ million in direct revenues per year. Another study has shown that losses to the lodging industry and to the local economy of New York City could actually amount to US $\$ 2.1$ billion with another US\$226 million lost annually in tax revenues for local, state and federal governments [23]. Moreover, due to the labor-intensive nature of hospitality businesses, hoteliers in New York City were forced to shed 2800 jobs in 2014 alone [23]. Guttentag and Smith [17] investigated the impact of Airbnb network growth on hotels by surveying 800 assist accommodation providers in attracting more customers and increase their sales and profits [38]. This study is attempting to understand and compare the main attributes that contribute to customer satisfaction for hotel and Airbnb apartment guests in Cluj-Napoca, Romania. Cluj-Napoca is a midsized city of some 350,000 inhabitants situated in the heart of Transylvania, about $500 \mathrm{~km}$ north of Bucharest, the capital of Romania.

A number of previous studies have used online reviews to measure customer satisfaction (see, for example, [13], [14], [15]); however, so far, only a few researchers have used text analytics to process and interpret this type of data (see, among others, [51], [55]). This study will also test the use of a text analytics software in the processing of satisfaction attributes.

tourists who had used Airbnb accommodations on whether they used these accommodations as substitute for hotels or not and why did they prefer Airbnb over hotels. They found that, indeed, twothirds of the surveyed tourists had used Airbnb as substitute for a hotel. Another study, conducted by a Morgan Stanley research group concluded that roughly $42 \%$ of Airbnb users are substituting for hotels [36]. These findings confirm that the growth of the Airbnb network may indeed threaten the profitability and, ultimately, the very existence of hotels.

Yet other studies have found that, while Airbnb listings may impact hotels, their effect is more complex and more nuanced than previously thought [6], [56]. According to this segment of the literature, Airbnb's impact will differ based on the characteristics of the hotel. For example, Zervas et al. [61] found that Airbnb's network of listings has a greater impact on lower-end hotels, independent hotels and hotels that did not cater to business travelers. Hajibaba and Dolnicar [20] confirmed that most affected by growth of the Airbnb network will be lower-end hotels while a newer study by Guttentag \& Smith [17] found that Airbnb substituted mixed-scale hotels to a larger degree. Other studies have shown that the impact of Airbnb listings on hotel revenues is more visible in the big cities and in areas where Airbnb listings have positive reviews [6],[25]. It affects mainly the leisure tourism segment and is mainly in the form of denying hotels the opportunity to increase price premium during peak periods [25].

Varma et al., [52] found that customers for hotel and Airbnb accommodations are quite different. In 
general business travelers prefer hotels and only turn to these platforms when hotel rooms are filled due to big trading shows taking place in the city while Airbnb serves for leisure and rarely for business travel [60]. Recognizing that hotels may offer business travelers amenities and services that most Airbnb accommodations do not, the platform has launched its Business Travel Ready initiative that is created to point out those listings that provide certain amenities that would make them suitable to business travelers [32].

\section{Attributes that determine satisfaction}

Studies on guest satisfaction started in the early 1970s. Satisfaction is a concept that measures to what extent tourists' expectations are fulfilled by their experience with a particular tourism product or service [41]. The most popular theory that explains satisfaction of tourists is the disconfirmation theory [37]. This theory postulates that customers are considered satisfied when the product or service meets or exceeds their expectation and could be considered dissatisfied when they experience a feeling of displeasure when they relate their actual experience to their expectation [9].

The products and services of accommodation providers that determine guest satisfaction are often represented as a set of attributes [42]. Following an extensive literature review of previous research we compiled a list of the most important attributes that determine guest satisfaction (for both hotels and Airbnb accommodations) which we present in a synthesized form in the table below (table 1).

Table 1. Main attributes that determine guest satisfaction (hotels and Airbnb accommodations)

\begin{tabular}{|c|c|c|c|}
\hline \multicolumn{2}{|r|}{ Hotel } & \multicolumn{2}{|r|}{ Airbnb } \\
\hline Study & Attributes & Study & Attributes \\
\hline [24] & $\begin{array}{c}\text { housekeeping, reception, food and beverage and } \\
\text { price }\end{array}$ & [16] & price, household amenities and authenticity \\
\hline$[10]$ & $\begin{array}{l}\text { room, front desk and security, while food and } \\
\text { recreation are less important }\end{array}$ & [36] & $\begin{array}{l}\text { price, authentic experience, location, own } \\
\text { kitchen and uniqueness of unit }\end{array}$ \\
\hline [8] & convenient location \& good service & {$[57]$} & $\begin{array}{l}\text { economic benefit, enjoyment and } \\
\text { sustainability }\end{array}$ \\
\hline$[31]$ & location & {$[45]$} & $\begin{array}{l}\text { social interaction with the host, attitude of } \\
\text { the host and location }\end{array}$ \\
\hline$[12]$ & $\begin{array}{l}\text { location, service quality, reputation, friendliness } \\
\text { of staff, price, room cleanliness and value for } \\
\text { money }\end{array}$ & [49] & $\begin{array}{l}\text { enjoyment, cost-savings and accommodation } \\
\text { amenities }\end{array}$ \\
\hline$[40]$ & the quality of tourist-staff interactions & [18] & $\begin{array}{l}\text { service, facility, location, feel welcome and } \\
\text { comfort of a home }\end{array}$ \\
\hline
\end{tabular}

Examining table 1, it quickly becomes obvious that the main attributes considered by guests for accommodation selection are very heterogeneous, a problem that was also pointed out by Dolnicar \& Otter [12]. This makes any attempt to compare in this format the main attributes of satisfaction as identified by guests of hotels and Airbnb accommodations very difficult.

More recently, a number of studies have attempted to compare the main accommodation attributes that generate satisfaction for Airbnb and hotel customers [4], [5], [17], [32], [33], [50], [51]. The results of these studies show that some attributes are common for both forms of accommodation, such as clean rooms and comfortable beds [51]. However, reviews for both hotels and Airbnb accommodations also focus on certain specific themes, which is what differentiates the two forms of accommodation, pointing out to their strengths and weaknesses.

Tussyadiah \& Zach [50] found that customers prefer hotels because of the conveniences (for example, airport shuttle services for guests, free parking, good breakfast options and in-room services) which cannot be found at Airbnb accommodations. The latter, however, could compensate by the hospitality of the host and by offering an accommodation with an atmosphere and with better and more suitable or more personalized facilities. Airbnb accommodations are also attractive because of their better situated locations. Mody [32] found that hotels are preferred by travelers who do not want to have surprises in terms of quality. They also prefer not to have to worry about security or hygiene, thus tend to choose hotels where these attributes are standardized. Airbnb guests, on the other hand, seek more diversity and local experiences; they want to experience the local community and desire to develop personal connections with the host and with people in the community. They perceive their Airbnb place as a home away from home.

Similar results were also found by Tussyadiah \& Zach [51] and Belarmino et al., [4]. According to them, Airbnb customers value the most the social interaction with the host and the characteristics of 
the neighborhood. In terms of the most appreciated hotel attributes the findings of the two studies are divergent. Tussyadiah \& Zach [51] found that guests tend to choose hotels over Airbnb accommodations for the quality and professionalism of the staff whereas in Belarmino et al.'s [4] study room amenities seemed to be more important.

\section{Analysis of online reviews}

Word-of-mouth (WOM) plays an important role in tourism marketing [27], especially because of the intangible nature of the industry [30], [54]. A tourism product cannot be returned in case of customer dissatisfaction the same way as a pair of shoes can; therefore travelers need to know in advance whether or not this product corresponds to their needs and expectations.

With the arrival of electronic platforms, consumer online reviews took on the role of WOM. Electronic word-of-mouth (eWOM), especially in the form of user-generated content (UGC), is more powerful than classical WOM [43] because it can reach more people, it is easy to understand [62] and it does not

\section{DATA AND METHODOLOGY}

For this study we compiled reviews published in English between May and November 2018 by users on booking.com and Airbnb. We included in our analysis a number of 1000 reviews, of which 500 were posted by hotel guests and 500 by Airbnb customers. We searched for hotel rooms/Airbnb listings available between 11 and 13 April 2019 for two guests. There were 904 accommodation possibilities for Cluj-Napoca listed on booking.com at the time of our search, with only 76 of them being hotels. Of these, we focused only on 3-5-star hotels with mean ratings over 7.0. Airbnb lists more than 300 accommodation units for Cluj-Napoca (the exact number varies depending on the day of the year and on the number of guests). We focused only on entire apartments/houses and only on those units that boasted five-star ratings.

In the first phase, we randomly selected one hotel or one Airbnb accommodation unit at a time and extracted all positive reviews in English posted between May and November 2018. We chose to analyze only positive reviews because previous studies established that positive reviews have a much stronger (positive) impact on consumers' decisions than negative reviews [54]. We, also, excluded those reviews that were too short and/or not relevant. After extracting all reviews that fit our criteria we moved on to the next hotel/Airbnb fade away with time [58]. Therefore, UGC is a powerful tool used to attract tourists to a destination and to market certain tourism products and services. The importance of UGC in the form of online reviews has increased over the last few years with the development of Web 2.0 platforms which encourage users to take a more active role in sharing their opinions and experiences with their peers [35]. Although a few studies have called the credibility of hospitality-related online reviews into question, these reviews have been proven to be more reliable and more trustworthy than any similar material posted by providers of hospitality products and services [3].

Reviews of hotels and other tourism accommodation rentals are increasingly used by travelers to select their accommodation, thus, facilitating independent travel planning. Many independent travelers are planning their trips and are booking their accommodations based on advice shared on electronic media by fellow travelers [26]. Good ratings of accommodation places could boost online reservations [59] and hep increase prices [39].

listing until we reached 1000 reviews. In the end, we included in our study 13 hotels (on average, 38.5 reviews for each hotel) and 38 Airbnb listings (13 reviews/listing).

Each review was initially recorded in an excel document and later exported to QDA Miner and coded as case. QDA Miner is a software package used for coding, annotating, retrieving and analyzing qualitative data in textual and photographic forms. The 1000 cases that were analyzed for this study included 2737 sentences and 30,153 words.

Next we extracted a number of codes that best describe the experience of travelers in their chosen accommodation. We coded each case manually because often words are misspelled or shortened and are, therefore, not picked up by the software. There may also be situations in which the software cannot understand the real meaning of the sentences. We started the process of coding from the list of the most frequent words. In the process we merged words with similar meanings. In the end, a total of 25 codes resulted, including apartment and hotel room. In the last part, we used the codes co-occurencies tool available in QDA Miner to better understand and visualize the relationships among these codes. 


\section{ANALYSIS}

The most frequent words, with a frequency of 50 or more in the 1000 cases analyzed for this study are presented in table 2 . We can see that the most frequent words are "location" (which appears 350 times in 342 different cases), "apartment" (334 times in 245 cases), "clean" (334 times in 331 different cases), "center" (245 times in 235 cases) and "room" (206 times across 174 cases). Other words that appear frequently are: "staff" (182 times in 176 cases), "breakfast" (175 times in 167 cases) and "near" (163 times in 154 cases). A word cloud was also computed for a better visualization of the most frequent words used by the guests in their reviews (figure 1).

Table 2. The most frequently used words in hotel and Airbnb guest reviews

\begin{tabular}{|c|c|c|c|c|}
\hline Word & Frequency & \% Shown & No. of cases & $\%$ cases \\
\hline location & 350 & 9.17 & 342 & 34.20 \\
\hline apartment & 334 & 8.75 & 245 & 24.50 \\
\hline clean & 334 & 8.75 & 331 & 33.10 \\
\hline center & 245 & 6.42 & 235 & 23.50 \\
\hline room & 206 & 5.40 & 174 & 17.40 \\
\hline staff & 182 & 4.77 & 176 & 17.60 \\
\hline breakfast & 175 & 4.59 & 167 & 16.70 \\
\hline near & 163 & 4.27 & 154 & 15.40 \\
\hline comfortable & 159 & 4.17 & 150 & 15.00 \\
\hline host & 156 & 4.09 & 152 & 15.20 \\
\hline stylish & 149 & 3.91 & 139 & 13.90 \\
\hline hotel & 144 & 3.77 & 122 & 12.20 \\
\hline walk & 121 & 3.17 & 111 & 11.10 \\
\hline friendly & 119 & 3.12 & 116 & 11.60 \\
\hline parking & 118 & 3.09 & 100 & 10.00 \\
\hline helpful & 114 & 2.99 & 112 & 11.20 \\
\hline cozy & 95 & 2.45 & 95 & 9.50 \\
\hline quiet & 80 & 2.10 & 79 & 7.90 \\
\hline check & 77 & 2.02 & 58 & 5.80 \\
\hline spacious & 70 & 1.83 & 69 & 6.90 \\
\hline old & 66 & 1.73 & 64 & 6.40 \\
\hline bed & 65 & 1.70 & 62 & 6.20 \\
\hline beautiful & 64 & 1.68 & 62 & 6.20 \\
\hline restaurants & 63 & 1.65 & 58 & 5.80 \\
\hline view & 59 & 1.55 & 55 & 5.50 \\
\hline easy & 57 & 1.49 & 55 & 5.50 \\
\hline big & 50 & 1.31 & 43 & 4.30 \\
\hline Total over 50 & 3815 & 100.00 & 1000 & \\
\hline
\end{tabular}

In the next step, we used the codes co-occurencies tool available in QDA Miner to determine the potential relationships among the codes. First a cooccurencies index was computed, followed by the application of a hierarchical cluster analysis and multi-dimensional scaling on all codes. The results are displayed in the form of dendograms, concept maps and proximity plots.

For example, figure 2 is a $2 \mathrm{D}$ concept map based on proximity values calculated on all codes. Each circle represents a code and the size of the circle is proportional with the frequency of the code. The distance between pairs of circles indicates how likely these codes tend to appear together.

Figure 2 shows that "apartment" tends to cooccur in a case with "nice design" and "good location" followed by "good communication" and "amenities". On the other hand, "hotel room" tends to be associated with "good breakfast", and - less frequently - with "spacious" and "parking". "Helpful host/staff", "clean" and "cozy" are situated about half distance between "apartment" and "hotel room" meaning that they are equally important for both forms of accommodation.

Another feature that allows us to explore relationships among codes and detect underlying patterns and structures of cooccurencies is the link analysis tool using a network graph (figures 3 and 4). The thickness of lines connecting the nodes and the numbers next to them show the strength of each relationship. 


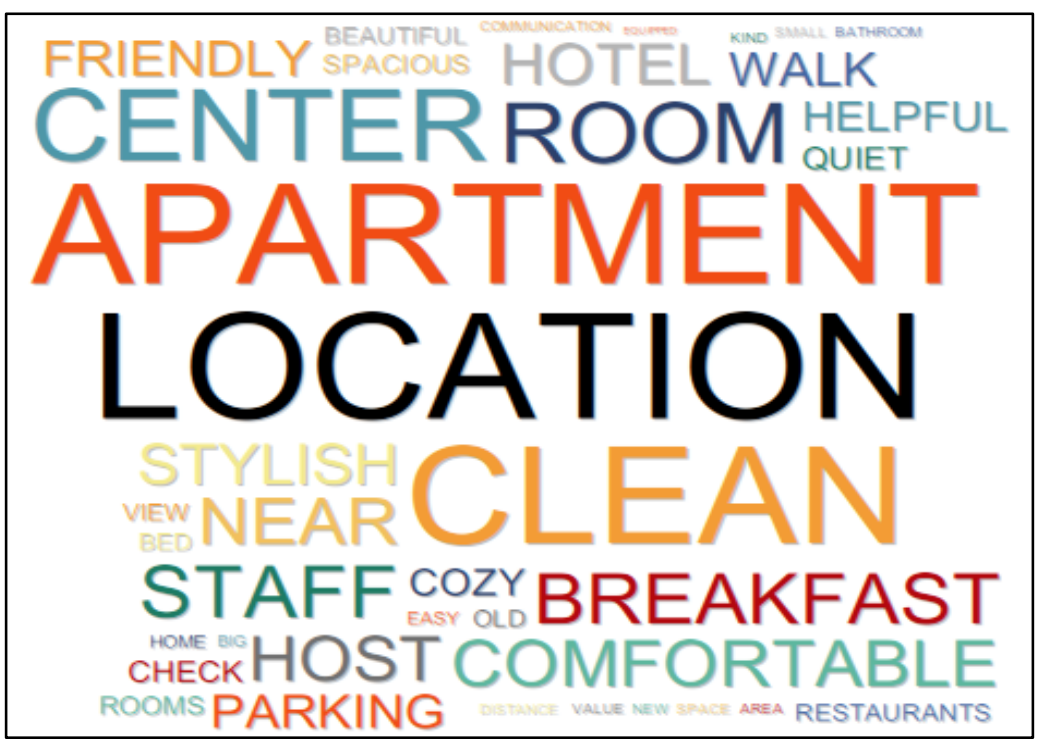

Figure 1. Word cloud with the most frequent words used in hotel and Airbnb guest reviews

Figure 3 shows the strength of relationships between "hotel room" and a number of descriptive codes. It reveals that the codes with the strongest association with hotel room are (in this order): "good breakfast" and "helpful staff", followed by "good location", "clean" and "spacious".

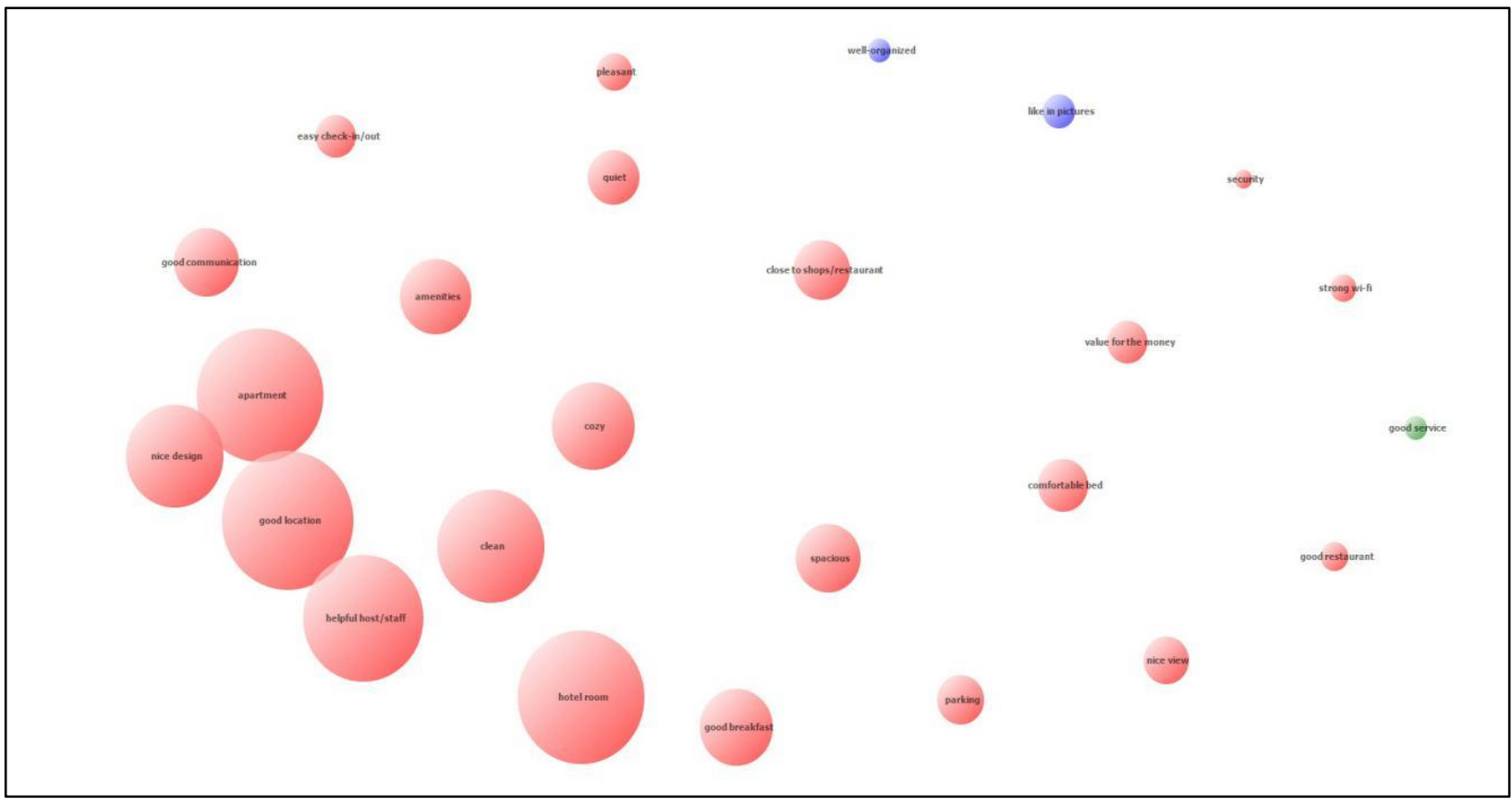

Figure 2. 2D concept map showing how likely codes tend to appear together

Figure 3 shows the strength of relationships between "hotel room" and a number of descriptive codes. It reveals that the codes with the strongest association with hotel room are (in this order): "good breakfast" and "helpful staff", followed by "good location", "clean" and "spacious".

Om the other hand, Airbnb apartments have the strongest association with "good location", "nice design" and "helpful host", followed by "clean" and "good communication" (figure 4).

Another tool to graphically display the distance between codes is the proximity plot. Figure 5 shows the distance of the 23 descriptive codes from the two codes denoting types of accommodation (hotel room and Airbnb apartment). All measured distances are from the 0 point. At 0 point there is absence of similarity or co-occurence. 


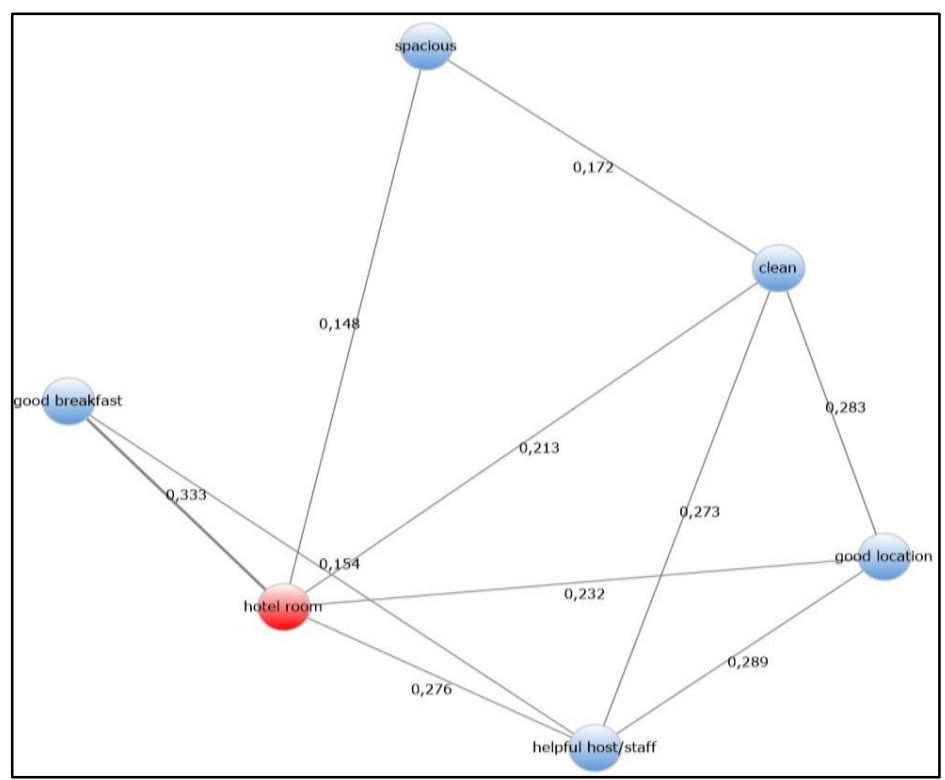

Figure 3. Link analysis to hotel room

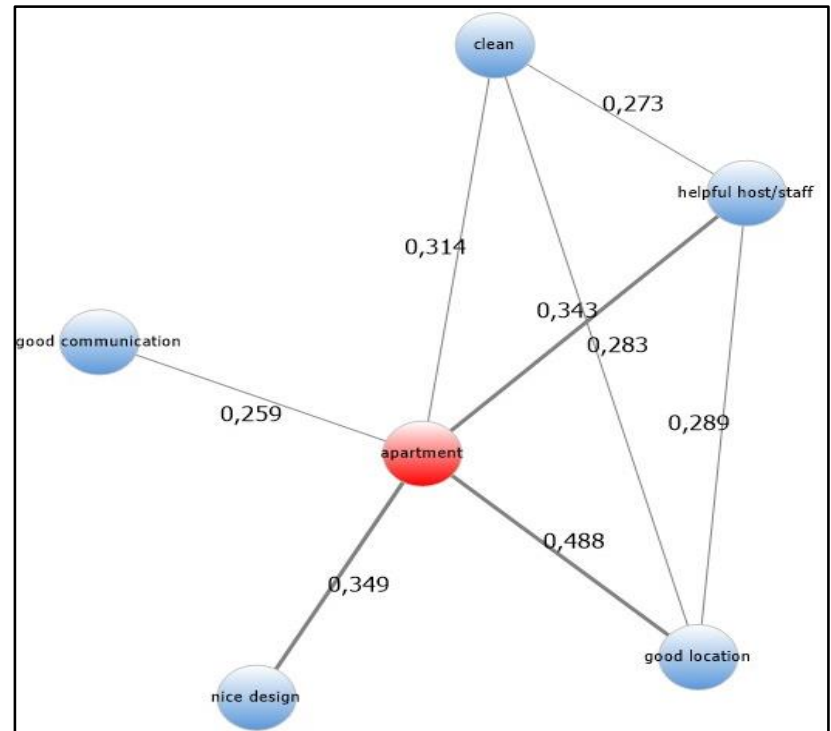

Figure 4. Link analysis to Airbnb apartment

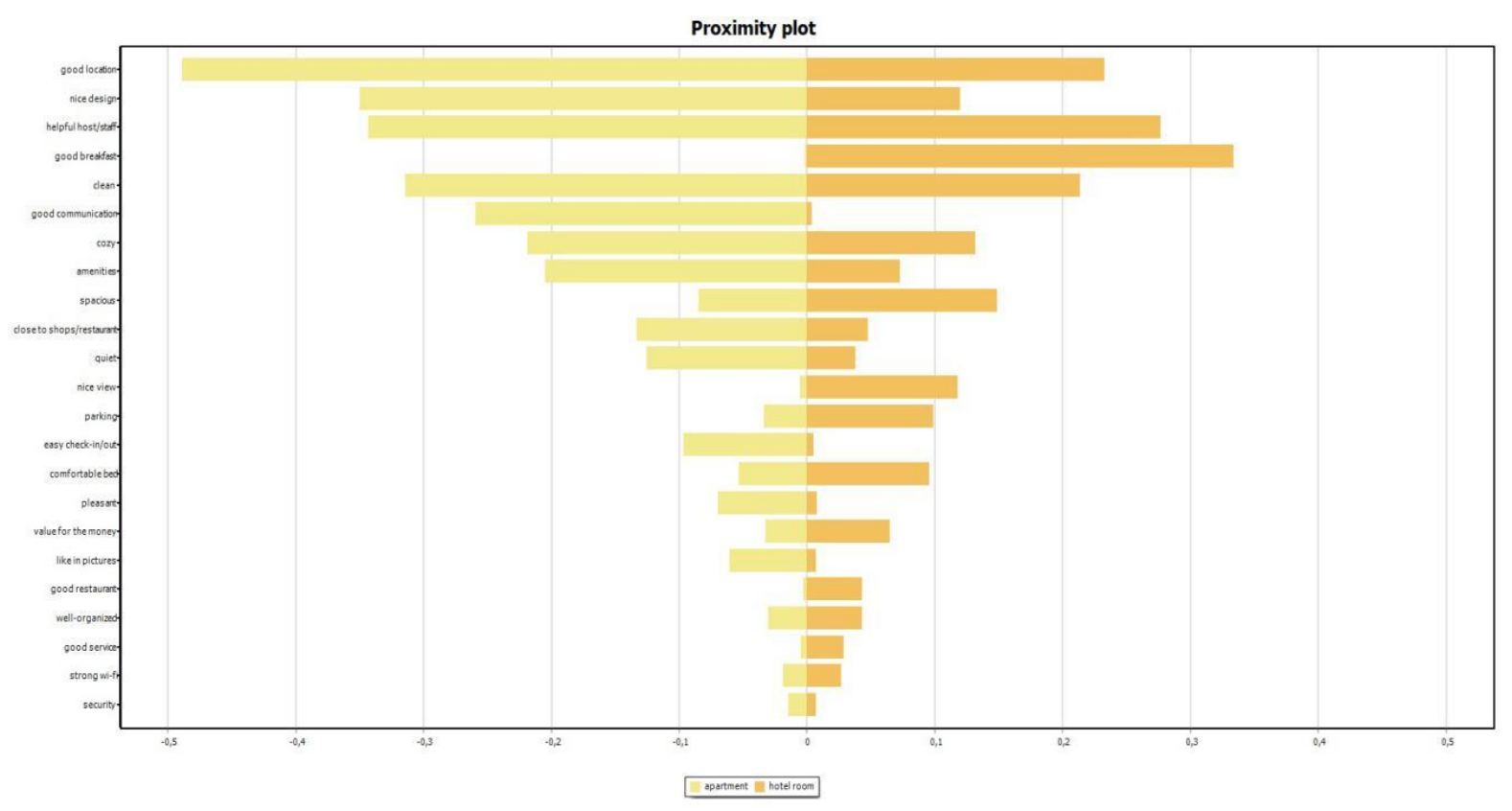

Figure 5. Proximity plot for hotel room/Airbnb apartment 
The proximity plot shows that, while "good location", "cleanliness", "helpful staff/host", "nice design", "cozy", "spacious" are important attributes for both types of accommodation, "good breakfast" was mentioned only by travelers staying in hotels (as the Airbnb rental apartments did not provide breakfast). "Good communication" and "easy check-in/out" were considered important by

\section{DISCUSSION AND CONCLUSIONS}

In this study, we used text analytics to examine and compare online reviews posted by users on booking.com and on Airbnb's platform. We found that the two lists of attributes that determine guest satisfaction are, to a great extent, similar. This means that guests have the same criteria in mind when evaluating their hotel and Airbnb stay, a conclusion that is consistent with the findings of Tussyadiah \& Zach [51] and can be explained by the fact that we considered for our analysis only those Airbnb listings that consisted of entire apartments/homes (the great majority of Airbnb accommodations in Cluj-Napoca) and excluded shared apartments or shared rooms. The owners do not live with the guests in the rental apartments and very often physical contact between hosts and guests is kept to the minimum. In fact, many reviewers of Airbnb accommodations mentioned never meeting the host in person despite having great (electronic) communication with the person. Thus, while good communication with the host was considered somewhat important for guest satisfaction, interacting or socializing (or the lack of) with the host was not an issue for most of the guests. Hosts are expected mainly to be helpful, to offer good advice and tips on what to find where or on where to go to live like a local. However, this attribute is not exclusive to Airbnb guests' list as hotel staff is also expected to be helpful.

Other important attributes that seem to be on top of both lists are "location", "clean", "cozy" and "nice design". While important for both types of guests, "location" has the strongest association with Airbnb apartments. Most guests considered that the ideal location for an Airbnb accommodation was close (within walking distance) to the city center, to the main tourist attractions and to restaurants and shops. For hotel guests, a good location generally meant either within walking distance from the city center, or a strategic position close to the airport, railroad station or highway. Also, while "nice design" seems to be important to both Airbnb and hotel guests, it displays a stronger association with Airbnb apartments, perhaps because hotel rooms are generally more standardized in terms of their interior design. Similarly, "clean" shows a somewhat stronger association with the Airbnb travelers staying in Airbnb apartments while "nice view" and "parking" were mentioned mainly by hotel guests. Although both overall less important descriptors, "value for the money" was mentioned more often by hotel guests, while "like in the pictures" is more associated with reviews of Airbnb apartments.

accommodation because the potential for (good or bad) surprises is greater there.

The most important, however, are those attributes that differentiate hotel guests from Airbnb guests. For Airbnb guests, these attributes are "good communication" and "easy check-in/out". In the case of hotels, these are pretty much taken for granted. Most hotels have reliable reservation systems and, if the booking is done through a platform, such as "booking.com", there is an added element of trust and reliability. Also, most hotels have staff on duty $24 / 7$ so the check-in/check-out process is generally straightforward, smooth and without complications. In the case of Airbnb apartments, however, good communication with host and an easy check-in/out system are essential to build trust and eliminate guests' fears.

On the other hand, one attribute that is considered important exclusively by hotel guests is "good breakfast". Indeed, many hotel reviewers have indicated that they selected their hotel based on this criterion. Those Airbnb listings that offer entire apartments do not provide breakfast. Instead, they may suggest places in the neighborhood where guests could have their breakfast or/and provide a full kitchen and all the necessary utensils for guests to prepare their own meals.

Other two attributes that were valued almost exclusively by hotel guests are "nice view" and "parking". Airbnb guests understand that most apartments are located in residential neighborhoods and do not come with a view or with a parking place. The limited parking space is generally used by the residents and parking for guests, if any, is generally on the curb.

Our study has a number of theoretical and managerial implications. Firstly, it has demonstrated that text analytics and online reviews could reliably be used to investigate and compare guest satisfaction in hotels and Airbnb accommodations. Secondly, the results of our study could be used by hotel managers to strengthen their position in the competition with the expanding Airbnb network. For example, they must ensure that they offer good breakfast and ample parking spaces in order to keep their loyal guests happy. 


\section{REFERENCES}

[1] Adamiak, C. (2018). Mapping Airbnb supply in European cities. Annals of Tourism Research, 71, 67-71.

[2] Airbnb (2018). Company website. https://www.airbnb.com.

[3] Albarq, A.N. (2014). Measuring the impacts of online word-of-mouth on tourists' attitude and intentions to visit Jordan: An empirical study. International Business Research, 71(1), 14-22.

[4] Belarmino, A., Whalen, E., Koh, Y., \& Bowen, J.T. (2019). Comparing guests' key attributes of peer-to-peer accommodations and hotels: mixed methods approach. Current Issues in Tourism, 22(1), 1-7.

[5] Birinci, H., Berezina, K. \& Cobanoglu, C. (2018). Comparing customer perceptions of hotel and peer-to-peer accommodation advantages and disadvantages. International Journal of Contemporary Hospitality Management, 30(2), 1190-1210

[6] Blal, I., Singal, M. \& Templin, J. (2018). Airbnb's effect on hotel sales growth. International Journal of Hospitality Management, 73, 85-92.

[7] Botsman, R. \& Rogers, R. (2010). What's mine is yours. New York: Harper Business

[8] Chan, E.S. \& Wong, S.C. (2006). Hotel selection: when price is not the issue. Journal of Vacation Marketing, 12(2), $142-159$.

[9] Choi, T.Y. \& Chu, R.K.S. (2001). Determinants of hotel guests' satisfaction and repeat patronage in the Hong Kong hotel industry. International Journal of Hospitality Management, 20, 277-297.

[10] Chu, R.K.S. \& Choi, T. (2000). An Importance-Performance analysis of hotel selection factors in the Hong Kong hotel industry: A comparison of business and leisure travelers. Tourism Management, 33(4), 776-789.

[11] Coyle, D. \& Yeung, T.Y. (2017). Understanding Airbnb in fourteen European cities. Tenth IDEI-TSE-IAST Conference on the Economics of Intellectual Properties, Software and the Internet, Toulouse, France, 12-13 January.

[12] Dolnicar, S. \& Otter, T. (2003). Which hotel attributes matter? A review of previous and a framework for future research. In, T. Griffin \& R. Harris (Eds.), Proceedings of the 9th Annual Conference of the Asia Pacific Tourism Association (APTA), University of Technology, Sydney, Australia, pp. 176-188. https://pdfs.semanticscholar.org/483b/94374944293d2a6d36cc1c97f0544ce3c79c.pdf

[13] Egresi, I. (2017). Tourists' satisfaction with shopping experience based on reviews on TripAdvisor. Tourism, 66(3), 330-340.

[14] Egresi, I. (2015). Tourists' shopping satisfaction in Istanbul's traditional markets. In, Proceedings of the Geobalcanica International Scientific Conference, Skopje, Macedonia, 5-7 June, pp. 291-298.

[15] Egresi, I. \& Prakash, T.G.S.L. (2019). What makes wildlife tourists happy and what disappoints them? Leaning from reviews posted on TripAdvisor. GeoJournal of Tourism and Geosites, 24(1), 102-117.

[16] Guttentag, D. (2015). Airbnb: Disruptive innovation and the rise of informal tourism accommodation sector. Current Issues in Tourism, 18(12), 1192-1217.

[17] Guttentag, A.D. \& Smith, S.L.J. (2017). Assessing Airbnb as a disruptive innovation relative to hotels: substitution and comparative performance expectations. International Journal of Hospitality Management, 64, 1-10.

[18] Guttentag, D, Smith, S., Potwarka, 1. \& Havitz, M. (2017). Why tourists choose Airbnb: A motivation-based segmentation study. Journal of Travel Research, 57(3), 342-359.

[19] Gyódi, K. (2017). Airbnb and the hotel industry in Warsaw: An example of the sharing economy? Central European Economic Journal, 2(49), 23-34.

[20] Hajibaba, H. \& Dolnicar, S. (2017). Substitutable by peer-to-peer accommodation networks? Annals of Tourism Research, 66, 185-188.

[21] Haywood, J., Hoyt, A., Wilson, C., Hennis, S., \& Alvarado, C. (2016). STR: Airbnb's impact minor on Manhattan hotels. Hotel News Now, February 9. http://www.hotelnewsnow.com/Articles/29639/STR-Airbnbs-impact-minoron-Manhattan-hotels

[22] Heo, C.Y., Blal, I., \& Choi, M. (2019). What is happening in Paris? Airbnb, hotels, and the Parisian market: A case study. Tourism Management, 70, 78-88.

[23] Hotel Association of New York City (2015). Report: Airbnb's billion negative impact on lodging industry and NYC economy. PR Newswire, October 30. https://www.prnewswire.com/news-releases/report-airbnbs-2-billion-negativeimpact-on-lodging-industry-and-nyc-economy-300169774.html

[24] Kandampully, J. \& Suhartanto, D. (2000). Customer loyalty in the hotel industry: The role of customer satisfaction and image. International Journal of Contemporary Hospitality Management, 12(6), 346-351.

[25] Lane, J. \& Woodworth, R.M. (2016). The sharing economy checks in: An analysis of Airbnb in the United States. CBRE Hotels' Americas Research. http://rss.hsyndicate.com/file/152006083.pdf

[26] Lawani, A., Reed, M.M.R., Mark, T. \& Zheng, Y. (2018). Reviews and price on online platforms: Evidence from sentiment analysis of Airbnb in Boston. Regional Science and Urban Economics, https://doi.org/10.1016/j.regsciurbeco.2018.11.003 
[27] Litvin, S.W., Goldsmith, R.E., \& Pan, B. (2018). A retrospective view of electronic word-of-mouth in hospitality and tourism management. International Journal of Contemporary Hospitality Management, 30(1), 313-325.

[28] Lockyer, T. (2005). The perceived importance of price as one hotel selection dimension. Tourism Management, 26(4), 529-537.

[29] Mahmood, A. (2016). The impact of Airbnb on hotel and hospitality industry. Hospitality Net, March 30. https://www.hospitalitynet.org/opinion/4081839.html

[30] Martin-Fuentes, E., Mateu, C., \& Fernandes, C. (2018). Does verifying users influence rankings? Analyzing Booking.com and TripAdvisor. Tourism Analysis, 23(1), 1-15.

[31] McCleary, K.W., Weaver, P.A., \& Hutchinson, J.C. (1993). Hotel selection factors as they relate to business travel situations. Journal of Travel Research, 32(2), 42-48.

[32] Mody, M. (2016). Creating memorable experiences: How hotels can fight back against Airbnb and other sharing economy providers. Boston Hospitality Review, 4(2), 1-10.

[33] Mody, M.A., Suess, C., \& Lehto, X. (2017). The accommodation experiencescape: A comparative assessment of hotels and Airbnb. International Journal of Contemporary Hospitality Management, 29(9), 2377-2404.

[34] Molz, J.G. (2013). Social networking technologies and the moral economy of alternative tourism: The case of coachsurfing.com. Annals of Tourism Research, 43, 210-230.

[35] Munar, A.M. (2010). Technological mediation and user created content in tourism. CIBEM Working Paper Series, April. Copenhagen Business School.

[36] Nowak, B., Allen, T., Rollo, J., Lewis, V., He, L., Chen, A., Wilson, W.N., Constantini, M., Hyde, O., Liu, K., Salvino, M., Chaudhry, B.A., Grube, A.M., \& Young, E. (2015). Global Insight: Who will Airbnb hurt more hotels or OTAs? Morgan Stanley Research, November 15.

[37] Oliver, R. (1980). A cognitive model of the antecedents and consequents of satisfaction decisions. Journal of Marketing Research, 17(4), 460-469.

[38] Oh, H. \& Parks, S.C. (1997). Customer satisfaction and service quality: A holistic perspective. International Journal of Hospitality Management, 18(1), 67-82.

[39] Öğüt, H. \& Onur Taş, B.K. (2012). The influence of internet customer reviews on the online sales and prices in hotel industry. The Service Industries Journal, 32, 197-214.

[40] Parasuraman, A., Zeithaml, V.A. \& Berry, I.L. (1988). SERVQUAL: A multiple-item scale for measuring consumer perceptions of service quality. Journal of Retailing, 64(1), 12-40.

[41] Pizam, A., Neumann, I. \& Reichel, A. (1978). Dimensions of tourism satisfaction with a destination area. Annals of Tourism Research, 5, 314-322.

[42] Qu, H., Ryan, B., \& Chu, R. (2000). The importance of hotel attributes in contributing to travelers' satisfaction in the Hong Kong hotel industry. Journal of Quality Assurance in Hospitality and Tourism, 1(3), 55-83.

[43] Schegg, R., Liebrich, A., Scaglione, M., \& Ahmad, S. (2008). An exploratory field study of Web 2.0 in tourism. In P. O’Connor, W. Hopken \& U. Gretzel (Eds.), Information and Communication Technologies in Tourism (pp. 152163). Vienna, Austria: Springer.

[44] Schor, J. (2016). Debating the sharing economy. Journal of Self-Governance and Management Economics, 4(3), 722.

[45] Sthapit, E. \& Jiménez-Barreto, J. (2018). Exploring tourists’ memorable hospitality experiences: An Airbnb perspective. Tourism Management Perspectives, 28, 83-92.

[46] Strømen-Bakhtiar, A. \& Vinogradov, E. (2018). The effects of Airbnb on hotels in Norway. Society and Economy. https://akademiai.com/doi/pdf/10.1556/204.2018.001

[47] Su, A. Y-L. (2004). Customer measurement practice in Taiwan hotels. International Journal of Hospitality Management, 23, 397-408.

[48] Sundararajan, A. (2016). The sharing economy: The end employment and the rise of crowd-based capitalism. Cambridge, MA: MIT Press.

[49] Tussyadiah, I.P. (2016). Factors of satisfaction and intention to use peer-to-peer accommodation. International Journal of Hospitality Management, 55, 70-80.

[50] Tussyadiah, I.P. \& Zach, F. (2017). Identifying salient attributes of peer-to-peer accommodation experience. Journal of Travel and Tourism Marketing, 34(5), 636-652.

[51] Tussyadiah, I. \& Zach, F. (2015). Hotels vs. peer-to-peer accommodation rentals: Text analytics of consumer reviews in Portland, Oregon. Travel and Tourism Association: Advancing Tourism Research Globally. https://scholarworks.umass.edu/cgi/viewcontent.cgi?article=1009\&context=ttra

[52] Varma, A., Jukic, N., Pestek, A., Shultz, C.J., \& Nestorov, S. (2016). Airbnb: exciting innovation or passing fad? Tourism Management Perspectives, 20, 228-237. 
[53] Verhage, J. (2016). One Wall Street firm expects Airbnb to book a billion nights a year within a decade. Bloomberg, April 11. http://www.bloomberg.com/news/articles/2016-04-11/one-wall-street-firm-expects-airbnb-to-book-abillion-nights-a-year-within-a-decade

[54] Vermeulen, I.E. \& Seegers, D. (2009). Tried and tested: The impact of online hotel reviews on consumer consideration. Tourism Management, 30, 123-127.

[55] Xiang, Z., Schwartz, Z., Gerdes, J.H., \& Uysal, M. (2015). What can big data and text analytics tell us about hotel guest experience and satisfaction. International Journal of Hospitality Management, 44, 120-130.

[56] Xie, K.L. \& Kwok, L. (2017). The effects of Airbnb's price positioning on hotel performance. International Journal of Hospitality Management, 67, 174-184.

[57] Yakin, V., Kacar, A.I., \& Ay, C. (2017). Sharing economy: Why the Turkish consumers use Airbnb? Journal of Marketing and Consumer Behavior in Emerging Markets, 2(6), 25-36.

[58] Yang, J., Mai, E., \& Ben-Ur, J. (2012). Did you tell me the truth? The influence of online community on eWOM. International Journal of Market Research, 64, 369-389.

[59] Ye, Q., Law, R., Gu, B., Chen, W. (2011). The influence of user-generated content on traveler behavior: An empirical investigation on the effects of e-word-of-mouth to hotel bookings. Computer Behavior, 27, 634-639.

[60] Young, C.A., Corsun, D.L., \& Xie, K.L. (2017). Travelers' preferences for peer-to-peer (P2P) accommodations and hotels. International Journal of Culture, Tourism and Hospitality Research, 11(4), 465-482. http://dx.doi.org/10.1108/IJCTHR-09-2016-0093.

[61] Zervas, G., Proserpio, D., \& Byers, J. (2017). The rise of the sharing economy: Estimating the impact of Airbnb on the hotel industry. Journal of Marketing Research, 54, 687-705.

[62] Zhang, L. \& Sun, X. (2017). Can travel information websites do better? Facilitating the decision-making experience for tourists. In S. Yamamoto (Ed.), Human Interface and Management Information: Supporting Learning Decision Making and Collaboration (pp. 302-311). Cham, Switzerland: Springer International. 